\title{
Cervical Cancer Awareness and Its Risk Factors Amongst Female Undergraduate Students of Rivers State University
}

\author{
Tamuno-Opubo Abiye ${ }^{1, *}$, Stanley Rosemary Oluchi ${ }^{2}$, Ezeugwu Sampson Ibekwe ${ }^{3}$, \\ Chimenem Simple Tamuno-Opubo ${ }^{4}$ \\ ${ }^{1}$ Department of Human Physiology, College of Medical Sciences Rivers State University, Port Harcourt, Nigeria \\ ${ }^{2}$ Department of Internal Medicine, College of Health Sciences, University of Port Harcourt, Port Harcourt, Nigeria \\ ${ }^{3}$ Department of Haematology, College of Health Sciences, University of Port Harcourt, Port Harcourt, Nigeria \\ ${ }^{4}$ Platinum Premier Medical Centre, Port Harcourt, Nigeria
}

Email address:

abiye.tamuno-opubo@ust.edu.ng (Tamuno-Opubo A.), rosemarystanley488@gmail.com (S. R. Oluchi), samcollino@yahoo.com (E. S. Ibekwe), chiosimpletams@yahoo.com (C. S. Tamuno-Opubo)

${ }^{*}$ Corresponding author

\section{To cite this article:}

Tamuno-Opubo Abiye, Stanley Rosemary Oluchi, Ezeugwu Sampson Ibekwe, Chimenem Simple Tamuno-Opubo. Cervical Cancer Awareness and Its Risk Factors Amongst Female Undergraduate Students of Rivers State University. Radiation Science and Technology. Vol. 6, No. 4, 2020, pp. 32-38. doi: 10.11648/j.rst.20200604.11

Received: April 5, 2020; Accepted: April 26, 2020; Published: December 31, 2020

\begin{abstract}
Cervical cancer has been associated with a high mortality rate among women in low- and middle-income countries such as Nigeria. Adequate knowledge and awareness of cervical cancer among women is essential for the control and prevention of deaths related to cervical cancer. A cross sectional study of the awareness of cervical cancer and associated risk factors was carried out in 253 students in Rivers state. The results showed that only 27 (11.5\%) have good knowledge of pap smear, $3(1.6 \%)$ indicated that they had done a pap smear and the findings were negative. Seventy-three $(35.6 \%)$ respondents were sexually active, with most of the respondents (74\%) that were sexually active reportedly had their first sexual experience between the $15-20$ years. The last sexual exposure was mostly within a year (64.4\%) among the respondents. Many of the respondents $(88.2 \%)$ reported having one sexual partner. Only $20.9 \%$ indicated that they were in a relationship and $73.5 \%$ of those in relationship admitted to using one form of contraception. The most commonly used contraceptive was a condom (7.2\%), followed by pills $(6.4 \%)$ among the sexually active students. Most of the respondents $(40.6 \%)$ indicated using contraceptive just once. The relationship of cervical cancer awareness and the demographic profile of the respondents were not statically associated or significant by age, faculty, level of study, marital status or education. However, level of knowledge of pap smear was statistically associated with current relationship status $(\mathrm{p}=0.007)$, having given birth $(0.036)$ and smoking habits $(\mathrm{p}<0.01)$ among the respondents.
\end{abstract}

Keywords: Cervical Cancer, Pap Smear, Risk Factors, Awareness, Risk, Undergraduates

\section{Introduction}

Cervical cancer is the most common gynaecological cancer and a leading cause of cancer death in women in Nigeria [1]. It is currently the fourth most frequent cancer in women with an estimated 570,000 new cases in 2018 representing $6.6 \%$ of all female cancers. Approximately $90 \%$ of deaths from cervical cancer occurred in low- and middle-income countries [2]. It is a leading cause of morbidity and mortality among women in the low- and middle-income countries (LMICs) [3]. the high incidence and mortality from cervical cancer in sub-Saharan Africa have been attributed to lack of awareness of cervical cancer among the population, health-care providers and policymakers; limited access to high-quality health-care services and cervical screening programmes; and lack of functional referral systems. All these lead to advanced stage at diagnoses. 4 In developed countries, incidence and mortality from cervical cancer have been reduced through measures which include cytological screening and 
prompt treatment of early cervical lesions [4, 5]. The uptake of screening programmes may be assisted by raising awareness about cervical cancer risk factors including young age at first sexual intercourse, [6-8] multiple male sexual partners, high parity, infections with the human papillomavirus, young age at first full-term pregnancy prolonged use of oral contraceptives and HIV infections [9-12]. Similarly, early help-seeking may be promoted if women in the LMICs become more aware of the symptoms of cervical cancer including intermenstrual vaginal bleeding, post-menopausal vaginal bleeding, postcoital vaginal bleeding, offensive vaginal discharge and lower abdominal pain [4, 13-15]. The appropriate awareness of cervical cancer has been reported to increase people's ability to detect early symptoms and signs of cancer [3]. In the United Kingdom [UK], knowledge and understanding of cancer risk factors and outcomes of cancer treatments influenced individuals' intentions and actual participation in cancer prevention programmes [16]. In addition, better knowledge of cancer warning signs has also been linked with early help-seeking [17]. Regarding cervical cancer, a substantial body of research has shown that awareness of cervical cancer and knowledge of its risk factors and symptoms can increase uptake of cervical screening and encourage early help- seeking for symptoms suggestive of cervical cancer [18]. However, there are limited data on levels of awareness about cervical cancer, including perceptions, beliefs and knowledge about cervical cancer risk factors and symptoms among young adults in Nigeria. The objective of this study was to investigate the awareness about cervical cancer risk factors and symptoms and beliefs about cervical cancer prevention among female undergraduate students in Rivers state, Nigeria.

\section{Methods}

\subsection{Study Area}

The study was carried out in the Rivers state University, Port Harcourt. The University is located in the Diobu area of Port Harcourt, Rivers State, Nigeria. The university consists of 9 academic faculties and 61 departments. The university host students from various socio-cultural backgrounds in Nigeria and serves as a catchment area for tertiary education in southern Nigeria.

\subsection{Study Design}

The descriptive cross-sectional study design was adopted for the study.

\subsection{Ethical Consideration}

Ethical approval for the study was obtained from the Research and Ethics committee of the Rivers State University prior to commencement of the study. Willing informed consent was also obtained from all willing participants in the study and no personal identifiers of the respondents were collected for the purpose of the study.

\subsection{Study Sample}

The target population for the study include female students that are at least 18 years old and are currently attending the Rivers state university. Two hundred and thirty-five (235) undergraduate students of the Rivers state University were selected by systematic random sampling for the study.

\subsection{Data Collection}

A structured interviewer-administered questionnaire was used to collect socio-demographic data, data on knowledge of cervical cancer, awareness of pap smear and risk factors for cervical cancer among the respondents.

\subsection{Data Analysis}

The data was analysed with the statistical package for social sciences (SPSS) version 25. All results were presented in mean, frequency and percentage as appropriate. Chisquare was used to assess the association of sociodemographic data and level of knowledge of cervical cancer among the respondents. All analysis was done at a $95 \%$ confidence interval and a p-value less than 0.05 was considered significant.

\section{Results}

Table 1 shows the demographic distribution of the respondents. Most of the respondents (52.8\%) were between $14-19$ years. Similarly, most of the respondents (49.8\%) were in 200 level and were Christians (97.4\%). Majority of the students (91.9\%) were also unemployed.

Table 2 showed the awareness of cervical cancer among the respondents. Many of the respondents $(71.5 \%)$ indicated that they have heard about cervical cancer. The most common source of the information among respondent that have heard about cervical cancer was the internet $(26.8 \%)$ followed by television (19.1\%) and school (18.3\%). The most common predisposing factors for cervical cancer as reported by the respondents were sexual intercourse $(29.8 \%)$, improper hygiene $(16.8 \%)$ and genetics $(9.8 \%)$. The respondents indicated that the symptoms for cervical cancer include; vaginal discharge (26.4\%), vaginal bleeding after sexual intercourse $(23.0 \%)$ and bleeding after attaining menopause $(4.7 \%)$. The general rating for awareness of cervical cancers showed that only $22.6 \%$ of the respondents had good awareness of cervical cancer.

Table 3 shows that the level of general awareness of Pap smear is poor in majority of the respondents, 208 (88.5\%). Only $27(11.5 \%)$ have good knowledge of pap smear, 3 $(1.6 \%)$ indicated that they had done a pap smear and the findings were negative.

Table 4 shows the distribution of risk factors for cervical cancer among the respondents. The results showed that 73 $(35.6 \%)$ were sexually active, with most of the respondents 
(74\%) that were sexually active reportedly had their first sexual experience between the $15-20$ years. The last sexual exposure was mostly within a year (64.4\%) among the respondents. Many of the respondents $(88.2 \%)$ reported having one sexual partner. Only $20.9 \%$ indicated that they were in a relationship and $73.5 \%$ of those in relationship admitted to using one form of contraception. The most commonly used contraceptive was a condom (7.2\%), followed by pills $(6.4 \%)$ among the sexually active students. Most of the respondents $(40.6 \%)$ indicated using contraceptive just once. Among the respondents, $36(15.3 \%)$ admitted having had an STI in the past, with most (73\%) indicating that the have had an STI only once and $18.9 \%$ indicated to having an STI twice. Majority of the respondents indicated that they treated their STI at the hospital $(47.2 \%)$ and at the local pharmacy store aka chemist $(36.1 \%)$. Only $50 \%$ of the respondents that have had an STI reported finished their treatment regimen for STI.

Table 1. Socio-demographic profile.

\begin{tabular}{|c|c|c|}
\hline Variable $(n=235)$ & Frequency & Percent \\
\hline \multicolumn{3}{|l|}{ Age } \\
\hline $14-19$ years & 124 & 52.8 \\
\hline $20-25$ years & 97 & 41.3 \\
\hline $26-31$ years & 14 & 6.0 \\
\hline \multicolumn{3}{|l|}{ Faculty } \\
\hline Agriculture & 10 & 4.3 \\
\hline Biomedical sciences & 15 & 6.4 \\
\hline College of health sciences & 20 & 8.5 \\
\hline Education & 25 & 10.6 \\
\hline Engineering & 26 & 11.1 \\
\hline Environmental sciences & 10 & 4.3 \\
\hline Humanities & 26 & 11.1 \\
\hline Law & 32 & 13.6 \\
\hline Management sciences & 17 & 7.2 \\
\hline Sciences & 30 & 12.8 \\
\hline Social sciences & 24 & 10.2 \\
\hline \multicolumn{3}{|l|}{ Level of study } \\
\hline 100 & 74 & 31.5 \\
\hline 200 & 117 & 49.8 \\
\hline 300 & 37 & 15.7 \\
\hline 400 & 7 & 3.0 \\
\hline \multicolumn{3}{|l|}{ Marital status } \\
\hline Single & 229 & 97.4 \\
\hline Married & 6 & 2.6 \\
\hline \multicolumn{3}{|l|}{ Religion } \\
\hline Christianity & 234 & 99.6 \\
\hline Islam & 1 & 0.4 \\
\hline \multicolumn{3}{|l|}{ Tribe } \\
\hline Igbo & 39 & 16.5 \\
\hline Ijaw & 23 & 9.8 \\
\hline Ikwerre & 40 & 17.0 \\
\hline Kalabari & 14 & 6.0 \\
\hline Ogba & 7 & 3.0 \\
\hline Ogoni & 12 & 5.1 \\
\hline Okrika & 8 & 3.4 \\
\hline Others & 27 & 11.5 \\
\hline \multicolumn{3}{|l|}{ Occupation } \\
\hline Student and unemployed & 216 & 91.9 \\
\hline Student and employed & 19 & 8.1 \\
\hline
\end{tabular}

Table 2. Awareness of cervical cancer.

\begin{tabular}{|c|c|c|}
\hline Variable $(n=235)$ & Frequency & Percent \\
\hline \multicolumn{3}{|l|}{ Have you heard of cancer of the cervix } \\
\hline Yes & 168 & 71.5 \\
\hline No & 67 & 28.5 \\
\hline \multicolumn{3}{|l|}{ If yes, how? } \\
\hline Radio & 19 & 8.1 \\
\hline Television & 45 & 19.1 \\
\hline Newspaper & 8 & 3.4 \\
\hline Magazine & 10 & 4.3 \\
\hline Internet & 63 & 26.8 \\
\hline Friend & 22 & 9.4 \\
\hline Relations & 12 & 5.1 \\
\hline Hospital & 32 & 13.6 \\
\hline School & 43 & 18.3 \\
\hline \multicolumn{3}{|c|}{ What is/are the predisposing factor (s) to cancer of the cervix } \\
\hline Sexual intercourse & 70 & 29.8 \\
\hline Genetics & 23 & 9.8 \\
\hline Mosquito bite & 0 & 0.0 \\
\hline Improper hygiene & 39 & 16.8 \\
\hline Sharing toilets & 11 & 4.7 \\
\hline I don't know & 55 & 23.4 \\
\hline \multicolumn{3}{|c|}{ What symptom (s) point to cancer of the cervix? } \\
\hline Vaginal discharge & 62 & 26.4 \\
\hline Vaginal bleeding after sexual intercourse & 54 & 23.0 \\
\hline Body rash & 8 & 3.4 \\
\hline Weight gain & 2 & 0.9 \\
\hline Bleeding after attaining menopause & 11 & 4.7 \\
\hline I don't know & 64 & 27.2 \\
\hline \multicolumn{3}{|c|}{ General rating for awareness of cervical cancer } \\
\hline Good & 38 & 22.6 \\
\hline Poor & 197 & 83.8 \\
\hline
\end{tabular}

Table 5 shows a distribution of other risk factors for cervical cancer among the respondents. Only 3.8\% of the respondents indicated that they have had given birth and 55.6\% of them indicated they had given birth just once. Most of the respondents (59.6\%) indicated that they take fruits and vegetables regularly. Only $4.7 \%$ of the respondent's smoke with majority indicating they have smoked for 1 year (45.5\%) and majority $(63.6 \%)$ indicated that they were occasional smokers. Only $9.4 \%$ indicated having a family history of cancer.

Table 6 showed that the relationship of cervical cancer awareness and the demographic profile of the respondents were not statically associated or significant by age, faculty, level of study, marital status or education.

Table 7 showed that level of knowledge of pap smear was statistically associated with current relationship status $(\mathrm{p}=0.007)$, having given birth (0.036) and smoking habits $(\mathrm{p}<0.01)$ among the respondents. 
Table 3. Awareness and Uptake of Pap smear.

\begin{tabular}{|c|c|c|}
\hline Variable $(n=235)$ & Frequency & Percent \\
\hline Have you heard about pap smear? & Yes & No \\
\hline Yes & 49 & 20.9 \\
\hline No & 186 & 79.1 \\
\hline \multicolumn{3}{|c|}{$\begin{array}{l}\text { If yes, do you know about pap smear as screening modality for cancer of } \\
\text { the cervix? } N=49\end{array}$} \\
\hline Yes & 37 & 75.5 \\
\hline No & 4 & 8.2 \\
\hline I don’t know & 8 & 16.3 \\
\hline \multicolumn{3}{|l|}{ If yes, how is pap smear done? $\mathrm{N}=49$} \\
\hline By using skin scrapings & 1 & 2.0 \\
\hline By using scalp scrapings & 2 & 2.2 \\
\hline By using cervical scrapings & 30 & 61.2 \\
\hline By using armpit hair & 1 & 2.0 \\
\hline I don't know & 17 & 34.7 \\
\hline \multicolumn{3}{|c|}{ Do you think screening for cancer of the cervix is necessary } \\
\hline Yes & 155 & 66.0 \\
\hline No & 23 & 9.8 \\
\hline I don’t know & 57 & 24.3 \\
\hline \multicolumn{3}{|c|}{ General rating on the knowledge of pap smear $(n=49)$} \\
\hline Good & 27 & 11.5 \\
\hline Poor & 208 & 88.5 \\
\hline \multicolumn{3}{|l|}{ Have you ever done a pap smear } \\
\hline Yes & 3 & 1.6 \\
\hline No & 190 & 98.4 \\
\hline \multicolumn{3}{|c|}{ If yes, how many times have you done it? } \\
\hline Once & 3 & 100.0 \\
\hline \multicolumn{3}{|l|}{ What year was the last one done? } \\
\hline 3 years go & 1 & 33.3 \\
\hline 4 years ago & 2 & 66.7 \\
\hline \multicolumn{3}{|l|}{ What health facility was it done } \\
\hline Clinic & 3 & 100.0 \\
\hline \multicolumn{3}{|l|}{ What was the result of the last one } \\
\hline Negative & 3 & 100.0 \\
\hline
\end{tabular}

\section{Discussion}

Knowledge of cervical cance and associated risk factors have been reported to correspond with an increased level of preventive measures among women with a consequent decline in incidence of mortality due to cervical cancer. An assessment of the awareness of cervical cancer among 253 female undergraduates in Rivers state Nigeria showed the $71.5 \%$ indicated that they have heard about cervical cancer. The most common source of the information among respondent that have heard about cervical cancer was the internet $(26.8 \%)$ followed by television (19.1\%) and school (18.3\%). This is consistent with the reports of similar studies across sub-Sharan Africa which showed that between $50-80 \%$ of women in urban cities reportedly have heard about cervical cancer [1821]. However, there are varying distributions on the source of information cervical cancer which is in contrast with the findings of this study. Other studies report TV/radio to be the most common source of information $(28-40 \%)$ for the women, followed by the internet which accounted for an average of $15 \%$ as a source of information for women in urban areas $[1,3,17,22]$. These difference could be attributed to the peculiar characteristics of the study population in the current study which are all students of a tertiary institution with the internet being the most popular source of information for a lot of tertiary students nowadays $[7,16,23]$.
Table 4. Risk factors for cervical cancer.

\begin{tabular}{|c|c|c|}
\hline Variable $(n=235)$ & Frequency & Percent \\
\hline \multicolumn{3}{|l|}{ Have you ever had sex } \\
\hline Yes & 73 & 35.6 \\
\hline No & 132 & 64.4 \\
\hline \multicolumn{3}{|c|}{$\begin{array}{l}\text { If yes, at what age did you first have sex } \\
(\mathrm{n}=73)\end{array}$} \\
\hline $9-14$ years & 4 & 5.5 \\
\hline $15-20$ years & 54 & 74 \\
\hline $21-26$ years & 15 & 20.5 \\
\hline \multicolumn{3}{|c|}{ When was your last sexual exposure $(n=45)$} \\
\hline Within a year & 29 & 64.4 \\
\hline More than a year ago & 15 & 33.3 \\
\hline 2 years ago & 1 & 2.2 \\
\hline \multicolumn{3}{|c|}{ How many partners did you have at that period? $(n=68)$} \\
\hline One & 60 & 88.2 \\
\hline Two & 6 & 8.8 \\
\hline Three & 2 & 2.9 \\
\hline \multicolumn{3}{|c|}{ Are you currently in any sexual relationship? $(n=116)$} \\
\hline Yes & 49 & 20.9 \\
\hline No & 186 & 79.1 \\
\hline \multicolumn{3}{|c|}{ If yes, do you use any form of contraception? } \\
\hline Yes & 36 & 73.5 \\
\hline No & 13 & 26.5 \\
\hline \multicolumn{3}{|c|}{ What type of contraceptives? } \\
\hline Condom & 17 & 7.2 \\
\hline Pills & 15 & 6.4 \\
\hline IUCD & 1 & 0.4 \\
\hline Safe period & 7 & 3 \\
\hline \multicolumn{3}{|c|}{ How long have you used contraception? } \\
\hline One & 13 & 40.6 \\
\hline Two & 12 & 37.5 \\
\hline Three & 4 & 12.5 \\
\hline Four & 1 & 3.1 \\
\hline Five & 2 & 6.3 \\
\hline \multicolumn{3}{|c|}{ How many sexual partners have you had in the past 3 months } \\
\hline None & 5 & 9.8 \\
\hline One & 36 & 70.6 \\
\hline Two & 7 & 13.7 \\
\hline Three & 2 & 3.9 \\
\hline Four & 1 & 2 \\
\hline \multicolumn{3}{|c|}{ Do you think your partner (s) is/are faithful? $(n=61)$} \\
\hline Yes & 32 & 52.5 \\
\hline No & 6 & 9.8 \\
\hline I don't know & 23 & 37.7 \\
\hline
\end{tabular}

Table 4. Continued.

\begin{tabular}{lll}
\hline Variable $(\mathbf{n}=\mathbf{2 3 5})$ & Frequency & Percent \\
\hline Have you ever had any sexually transmitted infection & \\
Yes & 36 & 15.3 \\
No & 199 & 84.7 \\
If yes, how many times have you had an STI? & & \\
Once & 27 & 73 \\
Twice & 7 & 18.9 \\
Thrice & 2 & 5.4 \\
Five times & 1 & 2.7 \\
How did you treat the last STI? & 17 & \\
Hospital & 13 & 47.2 \\
Chemist & 2 & 36.1 \\
Self-medication & 4 & 5.6 \\
No treatment & & 11.1 \\
Did you complete the drugs for the last one? & 19 & 50 \\
Yes & 19 & 50 \\
No &
\end{tabular}


Table 5. Other risk factors for cervical cancer.

\begin{tabular}{|c|c|c|c|}
\hline Variable & & Frequency & Percent \\
\hline \multicolumn{4}{|c|}{ Have you ever given birth } \\
\hline Yes & & 9 & 3.8 \\
\hline No & & 226 & 96.2 \\
\hline \multicolumn{4}{|c|}{ If yes, how many times } \\
\hline Once & & 5 & 55.6 \\
\hline Twice & & 2 & 22.2 \\
\hline Five times & & 2 & 22.2 \\
\hline \multicolumn{4}{|c|}{ Do you take fruits and vegetables regularly? } \\
\hline Yes & & 140 & 59.6 \\
\hline No & & 95 & 40.4 \\
\hline \multicolumn{4}{|c|}{ Do you smoke cigarettes? } \\
\hline Yes & & 11 & 4.7 \\
\hline No & & 224 & 95.3 \\
\hline \multicolumn{4}{|c|}{ If yes, for how long have you been smoking } \\
\hline One year & & 5 & 45.5 \\
\hline Two years & & 3 & 27.3 \\
\hline Three years & & 1 & 9.1 \\
\hline Four years & & 1 & 9.1 \\
\hline Ten years & & 1 & 9.1 \\
\hline \multicolumn{4}{|c|}{ How often do you smoke? } \\
\hline Daily & & 2 & 18.2 \\
\hline Weekly & & 1 & 9.1 \\
\hline Monthly & & 1 & 9.1 \\
\hline Occasionally & & 7 & 63.6 \\
\hline \multicolumn{4}{|l|}{ How many sticks } \\
\hline One & & 4 & 36.4 \\
\hline Two & & 4 & 36.4 \\
\hline Three & & 1 & 9.1 \\
\hline Four & & 1 & 9.1 \\
\hline Five & & 1 & 9.1 \\
\hline \multicolumn{4}{|c|}{ Is there anyone in your family that has had any form of cancer } \\
\hline Yes & & 22 & 9.4 \\
\hline No & & 213 & 90.6 \\
\hline \multicolumn{4}{|c|}{ If yes, what is your relationship } \\
\hline Cancer type & Family member & 1 & 11.1 \\
\hline Breast cancer & $\begin{array}{l}\text { Aunt ( } 2) \text { cousin } \\
(2), \text { niece }\end{array}$ & 5 & 55.6 \\
\hline Bone cancer & Uncle & 1 & 11.1 \\
\hline Prostate cancer & Father & & \\
\hline $\begin{array}{l}\text { No knowledge of } \\
\text { cancer type }\end{array}$ & Aunt, uncle & 2 & 22.2 \\
\hline
\end{tabular}

The most common predisposing factors for cervical cancer as reported by the respondents were sexual intercourse (29.8\%), improper hygiene (16.8\%) and genetics (9.8\%). The respondents indicated that the symptoms for cervical cancer include; vaginal discharge (26.4\%), vaginal bleeding after sexual intercourse $(23.0 \%)$ and bleeding after attaining menopause $(4.7 \%)$. These responses are consistent with reports of other publications which showed that vaginal bleeding and discharge are likely symptoms of cervical cancer $[1,2,24,25]$. The study showed that only $22.6 \%$ of the respondents had good awareness of cervical cancer and only 27 [11.5\%] have good knowledge of pap smear. This is relatively lower than the finding of Sadoh et al., [7] which reported that $40 \%$ of the students in Benin city had good awareness of cervical cancer. Similarly, Godson et al [9] reported that $35 \%$ of the students showed good awareness of cervical cancer. This is an indication that the awareness of cervical cancer among students in Rivers states is lower compared to other parts of the country.
Table 6. Relationship between cervical cancer awareness and sociodemographic profile.

\begin{tabular}{|c|c|c|}
\hline Variable $(n=235)$ & Frequency & Percent \\
\hline & \multicolumn{2}{|c|}{ Knowledge of cervical cancer } \\
\hline Age & Good & Poor \\
\hline $14-19$ years & $19(8.1)$ & $105(44.7)$ \\
\hline $20-25$ years & $15(6.4)$ & $82(34.9)$ \\
\hline $26-31$ years & $4(1.7)$ & $10(4.3)$ \\
\hline Chi-square & 1.690 & \\
\hline$P$ value & 0.430 & \\
\hline \multicolumn{3}{|l|}{ Faculty } \\
\hline Agriculture & $3(1.3)$ & $7(3.0)$ \\
\hline Biomedical sciences & $2(0.9)$ & $13(5.5)$ \\
\hline College of health sciences & $5(2.1)$ & $15(6.4)$ \\
\hline Education & $3(1.3)$ & $22(9.4)$ \\
\hline Engineering & $3(1.3)$ & $23(9.8)$ \\
\hline Environmental sciences & $4(1.7)$ & $6(2.6)$ \\
\hline Humanities & $3(1.3)$ & $23(9.8)$ \\
\hline Law & $4(1.7)$ & $28(11.9)$ \\
\hline Management sciences & $1(0.4)$ & $16(6.8)$ \\
\hline Sciences & $8(3.4)$ & $22(9.4)$ \\
\hline Social sciences & $2(0.9)$ & $22(9.4)$ \\
\hline Chi-square & 13.154 & \\
\hline$P$ value & 0.215 & \\
\hline \multicolumn{3}{|l|}{ Level of study } \\
\hline 100 & $13(5.5)$ & $61(26.0)$ \\
\hline 200 & $22(9.4)$ & $95(40.4)$ \\
\hline 300 & $3(1.3)$ & $34(14.5)$ \\
\hline 400 & $0(0.0)$ & $7(3.0)$ \\
\hline Chi-square & 3.829 & \\
\hline$P$ value & 0.280 & \\
\hline \multicolumn{3}{|l|}{ Marital status } \\
\hline Single & $37(15.7)$ & $192(81.7)$ \\
\hline Married & $1(0.4)$ & $5(2.1)$ \\
\hline Chi-square & 0.001 & \\
\hline$P$ value & 0.973 & \\
\hline \multicolumn{3}{|l|}{ Occupation } \\
\hline Student and unemployed & $32(13.6)$ & $184(78.3)$ \\
\hline Student and employed & $6(2.6)$ & $13(5.5)$ \\
\hline Chi-square & 3.621 & \\
\hline$P$ value & 0.057 & \\
\hline
\end{tabular}

The results showed that $73(35.6 \%)$ were sexually active, with most of the respondents (74\%) that were sexually active reportedly had their first sexual experience between the 15 20 years. This is consistent with the findings of other studies which report that between $60-80 \%$ of young adult females reported having their first sexual experience between $15-20$ years old in different parts of the country [1, 7, 9, 10, 17, 24]. The most commonly used contraceptive was a condom (7.2\%), followed by pills $(6.4 \%)$ among the sexually active students. Most of the respondents (40.6\%) indicated using contraceptive just once. This is consistent with the reports of other studies indicating that the most used forms of contraceptives are condoms and pills among female undergraduates (26-28).

Among the respondents, 36 (15.3\%) admitted having had an STI in the past, with most $(73 \%)$ indicating that the have had an STI only once and $18.9 \%$ indicated to having an STI twice. Majority of the respondents indicated that they treated their STI at the hospital (47.2\%) and at the local pharmacy store aka chemist (36.1\%). Only $50 \%$ of the respondents that have had an STI reported finished their treatment regimen for 
STI. The pattern and prevalence of STI observed in this study is in contrast with the findings of a similar study in Zaria which reported a lower STI prevalence of $10.5 \%$ (7).

Table 7. Relationship exposure to risk factors and level of awareness of Pap smear.

\begin{tabular}{|c|c|c|c|}
\hline \multirow{2}{*}{ Variables $(n=235)$} & \multicolumn{2}{|c|}{ Knowledge of pap smear } & \multirow{2}{*}{$\begin{array}{l}\text { Chi-square } \\
\text { (p-value) }\end{array}$} \\
\hline & \multicolumn{2}{|l|}{ n (\%) } & \\
\hline $\begin{array}{l}\text { Have you ever had } \\
\text { sex }\end{array}$ & Good & Poor & \\
\hline Yes & $13(6.3)$ & $60(29.3)$ & $3.33(0.068)$ \\
\hline No & $12(5.9)$ & $120(58.5)$ & \\
\hline \multicolumn{4}{|c|}{ If yes, at what age did you first have sex $(n=73)$} \\
\hline $9-14$ years & $1(1.4)$ & $3(4.1)$ & \multirow{3}{*}{$0.36(0.833)$} \\
\hline $15-20$ years & $10(13.7)$ & $44(60.3)$ & \\
\hline $21-26$ years & $2(2.7)$ & $13(17.8)$ & \\
\hline \multicolumn{4}{|c|}{ When was your last sexual exposure $(n=45)$} \\
\hline Within a year & $3(6.7)$ & $1(2.2)$ & \multirow{3}{*}{$0.39(0.823)$} \\
\hline More than a year ago & $7(15.6)$ & $12(26.7)$ & \\
\hline 2 years ago & $0(0.0)$ & $22(48.9)$ & \\
\hline \multicolumn{4}{|c|}{ How many partners did you have at that period? $(n=68)$} \\
\hline One & $11(16.2)$ & $49(72.1)$ & \multirow{3}{*}{$0.45(0.798)$} \\
\hline Two & $1(1.5)$ & $5(7.4)$ & \\
\hline Three & $090.0)$ & $2(2.9)$ & \\
\hline \multicolumn{4}{|c|}{$\begin{array}{l}\text { Are you currently in any sexual relationship? } \\
(\mathrm{n}=116)\end{array}$} \\
\hline Yes & $11(4.7)$ & $38(16.2)$ & \multirow[t]{2}{*}{$7.31(0.007)^{*}$} \\
\hline No & $16(6.8)$ & $170(72.3)$ & \\
\hline \multicolumn{4}{|c|}{ If yes, do you use any form of contraception? } \\
\hline Yes & $8(16.3)$ & $28(57.1)$ & \multirow[t]{2}{*}{$0.004(0.95)$} \\
\hline No & $3(6.1)$ & $10(20.4)$ & \\
\hline \multicolumn{4}{|c|}{ How many sexual partners have you had in the past 3 months } \\
\hline None & $2(3.9)$ & $3(5.9)$ & \multirow{5}{*}{$3.83(0.428)$} \\
\hline One & $5(5.8)$ & $31(60.8)$ & \\
\hline Two & $2(3.9)$ & $5(9.8)$ & \\
\hline Three & $1(2.0)$ & $1(2.0)$ & \\
\hline Four & $0(0.0)$ & $1(2.0)$ & \\
\hline \multicolumn{4}{|c|}{ Do you think your partner $(\mathrm{s})$ is/are faithful? $(\mathrm{n}=61)$} \\
\hline Yes & $7(46.7)$ & $1(6.7)$ & \multirow{3}{*}{$5.36(0.068)$} \\
\hline No & $1(6.7)$ & $2(13.3)$ & \\
\hline I don't know & $4(26.7)$ & $0(0.0)$ & \\
\hline \multicolumn{4}{|c|}{ Have you ever had any sexually transmitted infection } \\
\hline Yes & $6(12.2)$ & $3(6.1)$ & \multirow[t]{2}{*}{$0.59(0.440)$} \\
\hline No & $21(42.9)$ & $19(38.8)$ & \\
\hline \multicolumn{4}{|c|}{ Have you ever given birth } \\
\hline Yes & $3(1.3)$ & $6(2.6)$ & \multirow[t]{2}{*}{$4.391(0.036)^{*}$} \\
\hline No & $24(10.2)$ & $202(86.0)$ & \\
\hline \multicolumn{4}{|c|}{ Do you smoke cigarettes? } \\
\hline Yes & $5(2.1)$ & $6(2.06)$ & \multirow[t]{2}{*}{$13.09(<0.001)^{*}$} \\
\hline No & $22(9.4)$ & $202(86.0)$ & \\
\hline \multicolumn{4}{|c|}{ Is there anyone in your family that has had any form of cancer } \\
\hline Yes & $5(2.1)$ & $17(7.2)$ & $301(0.083)$ \\
\hline No & $22(9.4)$ & $191(81.3)$ & $3.01(0.085)$ \\
\hline
\end{tabular}

*Statistically significant $(\mathrm{p}<0.05)$.

The relationship of cervical cancer awareness and the demographic profile of the respondents were not statically associated or significant by age, faculty, level of study, marital status or education in the current study. This is in contrast with the findings of Saha [21] which reported that age and marital status were significantly associated with good levels of awareness of cervical cancer among students. However, in the current study, the level of knowledge of pap smear was statistically associated with current relationship status $(\mathrm{p}=0.007)$, having given birth (0.036) and smoking habits $(p<0.01)$ among the respondents. The results showed that most of respondents $(72.3 \%)$ that were not in a relationship had a poor awareness of pap smear. Similarly, $86 \%$ of the respondents that had not given birth were found to have a poor awareness of pap smear. Majority of the non-smokers (86.0\%) were also found to have a poor awareness of pap smear also. This finding is consistent with the findings of similar studies which indicated that a higher proportion of females that were not sexually active and not in a relationship had a poor level of awareness about pap smear [10, 25, 29]. This is an indication that birth history, sexual experience, contraceptive use and STI's are associated with the level of awareness of cervical cancer among women [5, 6, 10, 16, 25].

\section{Conclusion}

The findings of this study showed that most of the respondents had poor awareness of cervical cancer. The poor awareness was found to be significantly higher among students that reportedly have no sexual experience of have not given birth. Demographic information was not found to be associated with the level of awareness of cervical cancer and pap smear among the students. Based on the findings of the study, an increased level of awareness on cervical cancer is urgently needed among female undergraduates in Rivers state, Nigeria.

\section{References}

[1] Oluseyi Amu E. Awareness, Knowledge and Attitude to Cervical Cancer and Its Screening among Females in Somolu Local Government Area, Lagos, Nigeria. J Community Med Heal care. 2019; 4 (1): 1-6.

[2] WHO | Cervical cancer. WHO. 2018.

[3] Mwaka AD, Med M, Orach CG, Were EM, Lyratzopoulos G, Wabinga $\mathrm{H}$, et al. Awareness of cervical cancer risk factors and symptoms: cross-sectional community survey in postconflict northern Uganda.

[4] Perlman S, Wamai RG, Bain PA, Welty T, Welty E, Ogembo JG. Knowledge and awareness of HPV vaccine and acceptability to vaccinate in sub-Saharan Africa: A systematic review. PLoS One. 2014 Mar 11; 9 (3): e90912.

[5] Awodele O, Adeyomoye AA, Awodele DF, Fayankinnu VB, Dolapo DC. Cancer distribution pattern in southwestern Nigeria. Vol. 13, Tanzania Journal of Health Research. 2011.

[6] Githaiga JN, Walter FM, Scott SE, Mwaka AD, Moodley J. Symptom awareness measures for breast and cervical cancer in sub-Saharan Africa: A scoping review. South African J Oncol. 2019 Jun 26; 3.

[7] Sadoh AE, Okonkwo C, Nwaneri DU, Ogboghodo BC, Eregie $\mathrm{C}$, Oviawe O, et al. Effect of peer education on knowledge of human papilloma virus and cervical cancer among female adolescent students in Benin city, Nigeria. Ann Glob Heal. 2018; 84 (1): 121-8. 
[8] Mutambara J, Mutandwa P, Mahapa M, Chirasha V, Nkiwane $\mathrm{S}$, Shangahaidonhi T. Knowledge, attitudes and practices of cervical cancer screening among women who attend traditional churches in Zimbabwe. J Cancer Res Pract. 2017 Jun; 4 (2): 53-8.

[9] Eze GU, Obiebi IP, Umuago IJ. Perspectives of cervical cancer and screening practices among staff of a teaching hospital in South-South Nigeria. J Cancer Res Pract. 2018 Jun; 5 (2): $67-73$.

[10] Ali AN, Kar Mun L, Prajapati SK, Zahid Iqbal M, Zulfikar Ahmed N. Cervical cancer, its screening and vaccination: a KAP study among female healthcare students in a Private University, Malaysia. MOJ Bioequivalence Bioavailab. 2018 Oct 24; 5 (5).

[11] Balogun F, Omotade O. "She must have been sleeping around"...: Contextual interpretations of cervical cancer and views regarding HPV vaccination for adolescents in selected communities in Ibadan, Nigeria. PLoS One. 2018 Sep 1; 13 (9).

[12] Getachew S, Getachew E, Gizaw M, Ayele W, Addissie A, Kantelhardt EJ. Cervical cancer screening knowledge and barriers among women in Addis Ababa, Ethiopia. PLoS One. 2019 May 1; 14 (5).

[13] Mollers M, Lubbers K, Spoelstra SK, Weijmar-Schultz WCM, Daemen T, Westra TA, et al. Equity in human papilloma virus vaccination uptake?: Sexual behaviour, knowledge and demographics in a cross-sectional study in (un) vaccinated girls in the Netherlands. BMC Public Health. 2014 Mar 28; 14 (1): 288 .

[14] Kuguyo O, Matimba A, Tsikai N, Magwali T, Madziyire M, Gidiri M, et al. Cervical cancer in Zimbabwe: a situation analysis. Pan Afr Med J. 2017; 27: 215.

[15] Aldohaian AI, Alshammari SA, Arafah DM. Using the health belief model to assess beliefs and behaviors regarding cervical cancer screening among Saudi women: A cross-sectional observational study 11 Medical and Health Sciences 1117 Public Health and Health Services. BMC Womens Health. 2019 Jan 8; 19 (1): 6.

[16] Geremew AB, Gelagay AA, Azale T. Comprehensive knowledge on cervical cancer, attitude towards its screening and associated factors among women aged 30-49 years in Finote Selam town, northwest Ethiopia. Reprod Health. 2018 Feb 14; 15 (1).

[17] Toye MA, Okunade KS, Roberts AA, Salako O, Oridota ES, Onajole AT. Knowledge, perceptions and practice of cervical cancer prevention among female public secondary school teachers in Mushin local government area of Lagos State, Nigeria. Pan Afr Med J. 2017 Nov 10; 28.

[18] Ali SF, Ayub S, Manzoor NF, Azim S, Afif M, Akhtar N, et al. Knowledge and Awareness about Cervical Cancer and Its Prevention amongst Interns and Nursing Staff in Tertiary Care Hospitals in Karachi, Pakistan. Aziz SA, editor. PLoS One [Internet]. 2010 Jun 10 [cited 2020 Mar 24]; 5 (6): e11059.
Available from:

https://dx.plos.org/10.1371/journal.pone.0011059.

[19] Touch S, Oh JK. Knowledge, attitudes, and practices toward cervical cancer prevention among women in Kampong Speu Province, Cambodia. BMC Cancer. 2018 Mar 15; 18 (1): 294.

[20] Botha MH, Richter KL. Cervical cancer prevention in South Africa: HPV vaccination and screening both essential to achieve and maintain a reduction in incidence. Vol. 105, South African Medical Journal. South African Medical Association; 2015. p. 33-4.

[21] M. Yakout S. Cervical Cancer and Screening Test (PAP Test): Knowledge and Beliefs of Egyptian Women. Am J Nurs Sci. 2016; 5 (5): 175.

[22] Bisi-Onyemaechi AI, Chikani UN, Nduagubam O. Reducing incidence of cervical cancer: Knowledge and attitudes of caregivers in Nigerian city to human papilloma virus vaccination. Infect Agent Cancer. 2018 Aug 17; 13 (1).

[23] Liu T, Li S, Ratcliffe J, Chen G. Assessing knowledge and attitudes towards cervical cancer screening among rural women in eastern China. Int J Environ Res Public Health. 2017 Sep 1; 14 (9).

[24] Ahmed S, Ahmed R, Idris S, Sabitu K. Knowledge, attitude and practice of cervical cancer screening among market women in Zaria, Nigeria. Niger Med J [Internet]. 2013 [cited 2020 Mar 24]; 54 (5): 316. Available from: http://www.nigeriamedj.com/text.asp?2013/54/5/316/122337.

[25] Ifediora CO, Azuike EC. Knowledge and attitudes about cervical cancer and its prevention among female secondary school students in Nigeria. Trop Med Int Heal [Internet]. 2018 Jul 1 [cited 2020 Mar 24]; 23 (7): 714-23. Available from: http://doi.wiley.com/10.1111/tmi.13070.

[26] Saha A, Nag Chaudhury A, Bhowmik P, Chatterjee R. Awareness of cervical cancer among female students of premier colleges in Kolkata, India. Asian Pacific J Cancer Prev. 2010; 11 (4): 1085-90.

[27] Habtu Y, A, Yohannes S, A, Ersado TL, Aweke YH, et al. Knowledge, attitude and practice for cervical cancer prevention and control among women of childbearing age in Hossana Town, Hadiya zone, Southern Ethiopia: Communitybased cross-sectional study. PLoS One [Internet]. 2017 Jul 1 [cited 2020 Mar 24]; 12 (7). Available from: https://doi.org/10.1371/journal.pone.0181415.

[28] Mapanga W, Girdler-Brown B, Singh E. Knowledge, attitudes and practices of young people in Zimbabwe on cervical cancer and HPV, current screening methods and vaccination. BMC Cancer [Internet]. 2019 Aug 28 [cited 2020 Mar 24]; 19 (1): 845. Available from: https://bmccancer.biomedcentral.com/articles/10.1186/s12885 -019-6060-z.

[29] Ezenwa BN, Balogun MR, Okafor IP. Mothers' human papilloma virus knowledge and willingness to vaccinate their adolescent daughters in Lagos, Nigeria. Int J Womens Health. 2013; 5 (1): 371-7. 